\title{
Phytochemical studies, antiangiogenic, anti- inflammatory and antioxidant activities of Scyphocephalium ochocoa Warb. (Myristicaceae), medicinal plant from Gabon
}

Rick-Leonid Ngoua-Meye-Misso 1,2,5* (D), Jean De La Croix Ndong ${ }^{3}$, Cédric Sima-Obiang ${ }^{1,2}$, Joseph Privat Ondo ${ }^{1,2}$, Guy Roger Ndong-Atome ${ }^{1,2}$, Felix Ovono Abessolo ${ }^{4}$ and Louis-Clément Obame-Engonga ${ }^{1,2}$

\begin{abstract}
Background: The search for new anti-cancer molecules is one of the main concerns of oncology researchers. Scyphocephalium ochocoa is a plant of Myristicaceae family, used in traditional medicine against inflammatory diseases and several types of cancer. It is well established that free radicals, chronic inflammation and angiogenesis play an important role in initiation, tumor progression and metastasis formation. The aim of this study was to carry out a phytochemical screening, to determine the phenolic compounds content, to investigate the antiangiogenic, anti-inflammatory and antioxidant activities of water, water-ethanol and ethanol extracts of S. ochocoa.

Methods: Phytochemical screening and determination of phenolic compounds content were performed using standard methods. Antiangiogenic activity was assessed using chick chorioallantoic membrane (CAM) model and Drabkin test. Anti-inflammatory activity was estimated by protein denaturation and erythrocyte membrane stabilization method. Finally the antioxidant activity was appreciated by DPPH radical inhibition and phosphomolybdenum assay.

Results: The results of phytochemical studies show that extracts of bark of S. ochocoa are rich in polyphenols, tannins, flavonoids, proantocyanidins, saponosides, flavonols, flavanonols, sterol and triterpenes. The water extract showed good antiangiogenic activity $\left(I_{50}=1.153 \mu \mathrm{g} / \mathrm{mL}\right)$. Strong anti-inflammatory activity was observed with all extracts, $I C_{50}$ ranging from $34.775 \pm 2.543 \mu \mathrm{g} / \mathrm{mL}$ to $74.577 \pm 3.456 \mu \mathrm{g} / \mathrm{mL}$ for protein denaturation inhibition test and $\mathrm{IC}_{50}$ values ranging from $36.793 \pm 0.529 \mu \mathrm{g} / \mathrm{mL}$ at $48.912 \pm 0.957 \mu \mathrm{g} / \mathrm{mL}$ for antihemolytic activity. In addition, all extracts showed good antioxidant activity marked by a strong inhibition of the DPPH radical $\left(\mathrm{IC}_{50}\right.$ ranging from $4.969 \pm 0.263 \mu \mathrm{g} / \mathrm{mL}$ to $16.188 \pm 0.336 \mu \mathrm{g} / \mathrm{mL}$ and AAl ranging from $3.090 \pm 0.065$ to $10.080 \pm 0.517$ ) and by greater total antioxidant capacity (with contents ranging from $37.654 \pm 0.995$ to $131.302 \pm 1.102 \mathrm{VtCE}(\mathrm{mg}) / \mathrm{g}$ dry extract).

(Continued on next page)
\end{abstract}

\footnotetext{
* Correspondence: ngouamartel@gmail.com; ngouamartel@univ-masuku.ga

${ }^{1}$ Laboratory of Research in Biochemistry (LAREBIO), University of Sciences and

Technology of Masuku, Franceville, Gabon

${ }^{2}$ Laboratory of Natural Substances and Organometallic Synthesis, University

of Sciences and Technology of Masuku, Franceville, Gabon

Full list of author information is available at the end of the article
} 
(Continued from previous page)

Conclusion: Ultimately, these results could justify the use of S. ochocoa extracts in traditional medicine in the treatment of diseases related to angiogenesis and cancer, inflammatory diseases and diseases due to oxidative stress. A phyto-product with such a pharmacological profile could be a good candidate for the development of anticancer.

Keywords: Scyphocephalium ochocoa, Anti-inflammatory, Antiangiogenesis, Antioxidants, Chick Chorioallantoic membrane (CAM), Cancer

\section{Background}

Scyphocephalium ochocoa (S. ochocoa) belongs to the family of Myristicaceae and widespread in the littoral forests of Niger, Cameroon and Gabon [1]. Its vernacular names in Gabon are: Soghe, Sogho (Fang), Ossoko (Myene), Musuku (Nzebi, Punu-Shira), Otsoko, Soko (Tsogo) [2]. For its therapeutic and nutritional virtues, several populations of Central Africa use this plant. In Congo, a bark decoction is used for vaginal injection against female infertility. In a steam bath, mixing its leaves with those of Microdermis puberula, Costus afer, Macaranga barteri and Chorophora excelsa is used against febrile body aches [3]. It is also used as a decoction against gonorrhea or with salt and chili pepper [2]. In Gabon, the seeds of $S$. ochocoa are eaten grilled or looted. In traditional Gabonese medicine, a bark decoction is used in the treatment of anemia. As a drink, this decoction is used against rheumatism, joint pain, body aches and disorders of ovulation. The bark, dried and kneaded with white clay, serves to stop excessive milk secretions. This plant is also used in the treatment of several cancers: breast, stomach, skin and liver cancer.

The search for new anti-cancer molecules is one of the main concerns of researchers in oncology because, despite the advancement of medical technologies on cancer, this pathology remains among the main public health problems in the world with 14 million new cases and 8.8 million deaths in 2015 [4]. In Gabon, incomplete data available due to the lack of actual registration of the cancer population indicate that the number of new patients is constantly increasing from 183 new cases in 2000 to more than 1000 new patients in 2008 constituting a real public health problem [5]. According to the World Health Organization, metastases are the leading cause of cancer-related deaths [4]. Many studies have shown that reactive oxygen species (ROS), chronic inflammation and angiogenesis play an important role in initiation, tumor progression and metastasis formation [6, 7].

ROS, in cancer, are involved in the progression and proliferation of the cell cycle, cell survival and apoptosis, energy metabolism, cell morphology, cell-cell adhesion, cell mobility, angiogenesis, maintenance of the tumor and the formation of metastases $[7,8]$.
Other research has shown that there is a relationship between inflammation and cancer. In 1863, Virchow hypothesized that the origin of the cancer was at sites of chronic inflammation [9]. Inflammation acts as a tumor promoter via the pro-inflammatory cytokine TNF $\alpha$ (tumor necrosis factor- $\alpha$ ) which is important in the early stages of tumors, regulating a cascade of cytokines, chemokines, adhesions, matrix metalloproteinases (MMPs), and pro-biogenic [9, 10]. In addition, there is strong evidence that the use of nonsteroidal anti-inflammatory drugs (NSAIDs) such as aspirin reduces the risk of colon cancer and may be preventative for the respiratory tract, esophageal cancer and stomach cancer [11, 12]. Other NSAIDs, such as flurbiprofen, may have strong antimetastatic effects because of their inhibition of platelet aggregation [13].

Angiogenesis corresponds to all the processes leading to the formation of new blood capillaries by the outgrowth or budding of preexisting vessels [14]. Via the proangiogenic factor VEGF (vascular endothelial growth factor), angiogenesis is essential for tumor growth and for the formation of metastases because it supplies cancer cells with oxygen and nutrients [15].

ROS neutralization, inhibition of inflammation and angiogenesis may therefore be one of the strategies for finding anti-cancer products. Thus, in order to search for potential phyto-anticancer substances, this preliminary work consists in carrying out a phytochemical screening, in determining the content of phenolic compounds, in researching the antiangiogenic, anti-inflammatory and antioxidant activities of water, water-ethanol and ethanol extracts from S. ochocoa.

\section{Methods \\ Chemicals}

Butylated hydroxytoluene (BHT); 2,2-diphenyl-1-picryl-hydrazyl (DPPH); sorafenib p-toluenesulfonate salt (LC Laboratories; Woburn, MA, USA); Diclofenac (Combi-Blocks, Silverton, San Diego, CA, USA); quercetin, ethanol; ferric chloride; sulfuric acid; methanol; sodium phosphate; ammonium molybdate; chloridric acid; benzene; ammonium hydroxide; sodium chloride; Folin-Ciocalteu reagent; sodium bicarbonate; gallic acid 
and ascorbic acid were obtained from Sigma Chemical Co. (St. Louis, MO, USA).

\section{Plant material}

The barks of S. ochocoa were collected August 2015 in Mitzic, Woleu-Ntem (Northern of Gabon) (Fig. 1). They were identified at National Herbarium of IPHAMETRA, Libreville (Gabon). Voucher specimen has been deposited in the Herbarium of IPHAMETRA and at Laboratory of Biochemistry Research (LAREBIO) Department of Chemistry-Biochemistry, Faculty of Sciences of USTM in Franceville.

\section{Preparation of plant extract}

Barks were dried at ambient temperature of the Laboratory $\left(20-30{ }^{\circ} \mathrm{C}\right)$ and protected from light for several days. After drying, barks were crushed using a grinder (Laboratory Blender, Torrington, CT. USA). This powder was used for extractions by maceration method. Briefly, $200 \mathrm{~g}$ of powder was mixed with $2000 \mathrm{ml}$ of solvent (water, water-ethanol $(50 / 50, v / v)$ and ethanol). After $72 \mathrm{~h}$, the obtained extract was filtered using Whatman $\mathrm{N}^{\circ} 1$ filter paper. Ethanol and water-ethanol extracts were concentrated under reduced pressure at rotavapor (Büchi, Labortechnik, Switzerland) at $40{ }^{\circ} \mathrm{C}$ and $60{ }^{\circ} \mathrm{C}$, respectively. Water extract was lyophilized using a lyophilizer (Alpha 1-2 LDplus, Germany). All crude extracts obtained were stored at $4{ }^{\circ} \mathrm{C}$ until analysis.

\section{Phytochemical screening}

Each extract was then tested for the presence of flavonoids, coumarins, tannins, total phenolic, saponosids, cardiac glycosides, reducing sugar, sterols and triterpenes, oses and holosides, anthracenics, anthocyans, alkaloids and anthracenosids as described elsewhere $[16,17]$.

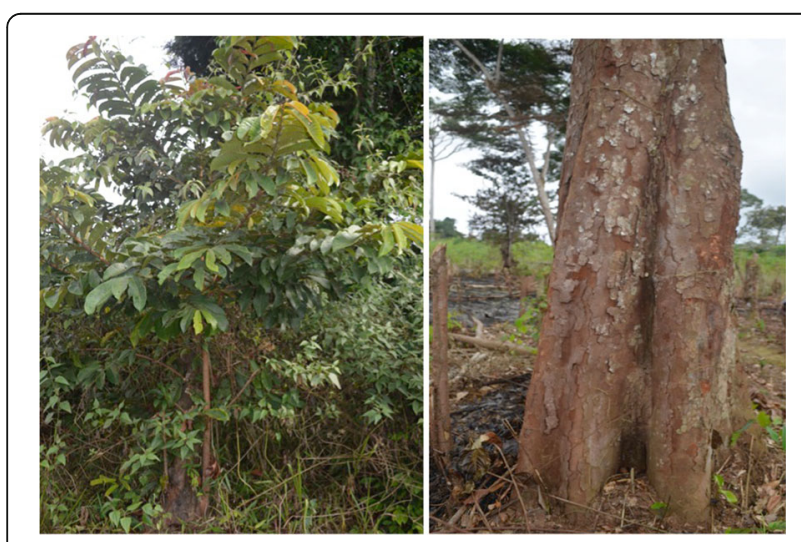

Fig. 1 Shrub and trunk of S. ochocoa. Photos taken at Mitzic, Woleu-Ntem (Northern of Gabon) by Ngoua-Meye-Misso with digital camera Cannon $16 \mathrm{M}$ pixel made in China

\section{Phenolic compound content}

Total phenolic content

The Folin-Ciocalteu method [18] with minor modifications was used to determine the total phenolic contents of the different extracts using gallic acid as standard. The absorbance was measured at $735 \mathrm{~nm}$ using a Spectrophotometre (Evolution 60S, USA). Results were expressed as gallic acid equivalent per gram of lyophilized sample (average of the triplicate analysis).

\section{Total flavonoid content}

The aluminum chloride $\left(\mathrm{AlCl}_{3}\right)$ colorimetric assay method [19] was used to determine total flavonoid contents, using quercetin as a standard. The absorbance was measured at $415 \mathrm{~nm}$ and total flavonoid contents were expressed as quercetin equivalents in milligrams per gram sample (average of the triplicate analysis).

\section{Tannins content}

Tannins content was determined according the reference method of European community [20]. The absorbance was measured at $525 \mathrm{~nm}$ and tannic acid was used as standard.

\section{Proanthocyanidins (PAs) content}

The proanthocyanidins content was determined according the method described by Prigent [21]. The absorbances were read at $550 \mathrm{~nm}$. Apple procyanidins were used as a standard. Results were expressed as apple procyanidins equivalent (APE).

\section{Antiangiogenic activity}

Antiangiogenic activity was evalued using Chick Chorioallantoic Membrane (CAM) Model acording to previously reported method [22, 23] with minors modifications. Brefly, fertilized chicken eggs were purchased from a local poultry farm, were sterilized with $70^{\circ}$ ethanol and incubated at $37^{\circ} \mathrm{C}$ in incubator (Ecocell, LSIS-B2V/EC55, Germany), with $80 \%$ relative humidity. On day 2 of post incubation, $3 \mathrm{~mL}$ of albumin were withdrawn to minimize adhesion of the shell membrane with CAM. A square window of $1 \mathrm{~cm}^{2}$ was opened in the egg shell at the opposite to blunt edge and sealed with an adhesive tape. The eggs were returned for further incubation.

\section{Drug administration}

At the 8th day, the experimental groups were divided into 5 of each containing 50 numbers of eggs. Group 1, 2, 3 and 4 were treated with water extracts and sorafenib (positive control). Sterile discs (diameter: $10 \mathrm{~mm}$ ) of Whatman $\mathrm{N}^{\circ} 1$ soaked of $10 \mu \mathrm{L}$ of the water extract from S. ochocoa and sorafenib at concentrations ranging from $60,125,250$ to $500 \mu \mathrm{g} / \mathrm{mL}$ was applied to the CAM. In 
parallel Group 5 treated with phosphate buffered saline (PBS) alone as negative control, a paper disc Whatman $\mathrm{N}^{\circ} 1$ soaked of $10 \mu \mathrm{L}$ PBS at $\mathrm{pH} 7.4$ was placed on the CAM of egg. The treated CAM samples were incubated for $48 \mathrm{~h}$.

\section{Angiogenesis quantification}

After $48 \mathrm{~h}$ of incubation at $37{ }^{\circ} \mathrm{C}$ and $80 \%$ relative humidity, a volume of $10 \mu \mathrm{L}$ of formaldehyde at $4 \%$ was applied to the CAM. 5 min later, the CAM was cut around the disk and all (disc and CAM) was placed in a Petri. Then the photos were taken with a Nikon digital camera D5100 (made in Thailand) and the images were subsequently analyzed with the software Image J. The numbers of vessel branch points contained in a circular region (equal to the area of each filter disk) were counted manually. The percentage of vascularization (density) is measured relative to a normal control vascularization. The ability to inhibition angiogenesis was calculated by the following equation:

$$
\% \mathrm{AIA}=\left[\left(\mathrm{Nbv}_{\text {control}^{-}} \mathrm{Nbv}_{\text {sample }}\right) / \mathrm{Nbv}_{\text {control }}\right] \times 100
$$

$\mathrm{Nbv}=$ number of blood vessel branch points. The $\mathrm{IC}_{50}$ (concentration providing 50\% inhibition) of extracts and standards was determinate using regression curves in the linear range of concentrations. The experiments have been repeated at least four times, and the results were reproducible.

\section{Drabkin reagent test}

The determination of hemoglobin in CAM sections was done by the Drabkin and Austin [24] assay method. The dissected CAM sections were crushed with a pestle and mortar. The pilate was mixed with $5 \mathrm{ml}$ of cooled normal salt solution and then homogenized. The resulting solution was centrifuged at $2500 \mathrm{rpm}$ for $30 \mathrm{~min} .3 \mathrm{~mL}$ of Drabkin reagent was added to $1 \mathrm{~mL}$ of supernatant. The reaction was incubated at room temperature $\left(27 \pm 3{ }^{\circ} \mathrm{C}\right)$ for $20 \mathrm{~min}$ and the absorbance measured at $580 \mathrm{~nm}$ using a UV spectrophotometer (Evolution $60 \mathrm{~S}$, USA). All tests were performed in triplicate to ensure reproducibility of the result.

\section{Toxicity of extracts}

Toxicity of extracts was determined by observation of embryos statue after extracts actions on vascularization according to a previously reported methods [25].

\section{Anti-inflammatory activity}

The anti-inflammatory activity was evaluated by protein denaturation method and membrane stabilization method.

\section{Protein anti-denaturation test}

Protein denaturation methods have been used [26, 27] with slight modifications mentioned by Ngoua-Meye-Misso et al. [28]. $0.1 \mathrm{~mL}$ of fresh chicken egg albumin was mixed with $1.9 \mathrm{~mL}$ of phosphate buffered saline (PBS, pH 6.4) and $1 \mathrm{~mL}$ of varying concentration of extract $(6.25,12.5,25,50$ and $100 \mu \mathrm{g} / \mathrm{mL})$. A similar volume of distilled water served as a negative control. Then the mixtures were incubated at $37{ }^{\circ} \mathrm{C}$ in an incubator (Ecocell, LSIS-B2V/EC55, Germany) for $20 \mathrm{~min}$ and then heated at $70{ }^{\circ} \mathrm{C}$ for $5 \mathrm{~min}$. After cooling, the absorbances were measured at $660 \mathrm{~nm}$ on the spectrophotometer (Evolution 60S, USA). Sodium diclofenac in the final concentrations of $31.25,62.5,125,250$ and $500 \mu \mathrm{g} / \mathrm{mL}$, was used as a reference drug and similarly treated for the determination of absorbance.

$$
\text { Inhibition }(\%)=\left[\left(\mathrm{Abs}_{\text {sample }}-\mathrm{Abs}_{\text {control }}\right) / \mathrm{Abs}_{\text {control }}\right] \times 100
$$

Abs = absorbance. The concentration of the extract for $50 \%$ inhibition $\left(\mathrm{IC}_{50}\right)$ was determined by the dose-response curve.

\section{Membrane stabilization test}

The membrane stabilization test was evaluated by the method of hemolysis of red blood cells. This hemolysis was induced on the one hand by heat on the other hand by distilled water [29] with some modifications.

\section{Preparation of the suspension of erythrocytes}

Fresh whole blood $(3 \mathrm{~mL})$ collected from healthy volunteers in EDTA tubes was centrifuged at $2500 \mathrm{rpm}$ for $10 \mathrm{~min}$ at $4{ }^{\circ} \mathrm{C}$. A volume of normal saline equivalent to that of supernatant was used to dissolve the red blood cells. The volume of dissolved red blood cells obtained was measured and reconstituted in the form of a $40 \% \mathrm{v} /$ $\mathrm{v}$ suspension with isotonic buffer solution $(10 \mathrm{mM}$ sodium phosphate buffer, $\mathrm{pH}$ 7.4). The buffer solution contained $0.2 \mathrm{~g}$ of $\mathrm{NaH}_{2} \mathrm{PO}_{4}, 1.15 \mathrm{~g}$ of $\mathrm{Na}_{2} \mathrm{HPO}_{4}$ and $9 \mathrm{~g}$ of $\mathrm{NaCl}$ in $1 \mathrm{~L}$ of distilled water. Reconstituted red blood cells (supernatant resuspended) were used as such. The study protocol was performed according to the Helsinki declaration and approved by the Ethics Committee of Gabon ( ${ }^{\circ} 009$ March 2013).

\section{Hemolysis induced by heat}

Samples of used extracts were dissolved in isotonic phosphate buffer solution. A set of 5 centrifugation tubes containing respectively $2 \mathrm{~mL}$ of extracts at increasing concentrations $(15.625,31.25,62.5,125$ and $250 \mu \mathrm{g} / \mathrm{mL})$. Sodium diclofenac, with the same concentration range was used as the reference medicine. The negative control contained $2 \mathrm{~mL}$ of distilled water. A suspension of $0.1 \mathrm{~mL}$ of red blood cells was added to each of the tubes and 
mixed gently. The tubes were incubated at $54{ }^{\circ} \mathrm{C}$ for $20 \mathrm{~min}$ in a water bath. After incubation, tubes were centrifuged at $2500 \mathrm{rpm}$ for $10 \mathrm{~min}$ at $4{ }^{\circ} \mathrm{C}$ and the hemoglobin content of the supernatant was estimated using the spectrophotometer (Evolution 60S, USA) at $540 \mathrm{~nm}$. The percentage of inhibition by the extract was calculated as follows:

$\%$ Inhibition of hemolysis $=\left(1-\mathrm{OD}_{\text {sample }} / \mathrm{DO}_{\text {control }}\right) \times 100$

Where OD sample = absorbance of the sample; $\mathrm{DO}_{\text {con- }}$ trol $=$ absorbance of the control. The concentration of the extract for $50 \%$ inhibition $\left(\mathrm{IC}_{50}\right)$ was determined by the dose-response curve.

\section{Hemolysis induced by hypotonicity}

The extract samples were dissolved in distilled water (hypotonic solution) at different concentrations obtained by double dilution $(15.625,31.25,62.5,125$ and $250 \mu \mathrm{g} /$ $\mathrm{mL}$ ). Sodium diclofenac, at the same concentrations, was used as a reference medicine. Distilled water was used as a negative control. $2 \mathrm{ml}$ of sample were mixed with $0.1 \mathrm{~mL}$ of a suspension of erythrocytes and then the mixtures were incubated for $1 \mathrm{~h}$ at $37{ }^{\circ} \mathrm{C}$. The tubes were then centrifuged at $2500 \mathrm{rpm}$ for $10 \mathrm{~min}$ at $4{ }^{\circ} \mathrm{C}$. the hemoglobin content of the supernatant was estimated using the spectrophotometer (Evolution 60S, USA) at $540 \mathrm{~nm}$. The percentage of hemolysis was calculated assuming hemolysis produced in the presence of distilled water as $100 \%$. The percentage inhibition of hemolysis by the extract was calculated as follows:

$\%$ Inhibition of hemolysis $=\left(1-\mathrm{OD}_{\text {sample }} / \mathrm{DO}_{\text {control }}\right) \times 100$

Where OD sample = absorbance of the sample; $\mathrm{DO}_{\text {con- }}$ trol $=$ absorbance of the control. The concentration of the extract for $50 \%$ inhibition $\left(\mathrm{IC}_{50}\right)$ was determined by the dose-response curve.

\section{Observation of erythrocyte membranes}

A blood smear was performed before and after treatment with the extracts to observe the appearance of erythrocyte membranes. $5 \mu \mathrm{L}$ of sample was deposited and spread on the slide. After drying, fixing with methanol and stained with Giemsa, the cells were observed under an optical microscope (Motic Digital Microscope) coupled to a computer using the Motic image plus 2.0 software and the photos were taken.

\section{Antioxidant activity DPPH test}

The method described by Scherer and Godoy [30], based on DPPH radical test, was used to determine the Antioxidant Activity Index (AAI). Briefly, DPPH solution was prepared by dissolving $10 \mathrm{mg}$ of DPPH powder in
$100 \mathrm{~mL}$ methanol. Graded concentrations of extracts ranging from 3.125 to $100 \mu \mathrm{g} / \mathrm{mL}$ obtained by two-fold dilutions were prepared and $1 \mathrm{~mL}$ of each dilution were mixed with $1 \mathrm{~mL}$ of the working solution of $\mathrm{DPPH}$ $(100 \mu \mathrm{g} / \mathrm{mL})$. Absorbencies were measured at $517 \mathrm{~nm}$ after $15 \mathrm{~min}$ incubation at room temperature in the dark. Ascorbic acid (vitamin C), Butylated hydroxytoluene (BHT) and quercetin were used as references. The ability to scavenge DPPH radical was calculated by the following equation:

$$
\% \operatorname{RSA}=\left(\mathrm{A}_{\text {control }}-\mathrm{A}_{\text {sample }} / \mathrm{A}_{\text {control }}\right) \times 100
$$

$\mathrm{A}=$ absorbance at $517 \mathrm{~nm}$. The $\mathrm{IC}_{50}$ (concentration providing 50\% inhibition) of extracts and standards was determinate using regression curves in the linear range of concentrations. The AAI was then calculated as follows: $\quad \mathrm{AAI}=[\mathrm{DPPH}] \quad \mathrm{f} \quad\left(\mu \mathrm{g} \cdot \mathrm{mL}^{-1}\right) / \mathrm{IC}_{50} \quad\left(\mu \mathrm{g} \cdot \mathrm{mL}^{-1}\right)$, $[\mathrm{DPPH}]_{\mathrm{f}}$ is the final concentration of DPPH $(50 \mu \mathrm{g} / \mathrm{mL})$. We considered criteria of Scherer and Godoy (2009) according to which plant extracts show poor antioxidant activity when $\mathrm{AAI}<0.5$, moderate antioxidant activity when AAI between 0.5 and 1.0, strong antioxidant activity when AAI between 1.0 and 2.0, and very strong when AAI $>2.0$.

\section{Total antioxidant capacity}

The assay was based on the reduction of Mo (VI) to Mo (V) and subsequent formation of a green phosphate/ Mo (V) complex in acid pH [31]. A total volume of $0.3 \mathrm{~mL}$ extract dissolved in methanol was added to $3 \mathrm{~mL}$ of reagent solution $(0.6 \mathrm{~mol} / \mathrm{L}$ sulphuric acid, $28 \mathrm{mmol} / \mathrm{L}$ sodium phosphate and $4 \mathrm{mmol} / \mathrm{L}$ ammonium molybdate). The mixtures were incubated at $70{ }^{\circ} \mathrm{C}$ for $90 \mathrm{~min}$ then cooled to room temperature. The absorbance was measured at $695 \mathrm{~nm}$. The total antioxidant activity was expressed as the number of equivalence of ascorbic acid, $\mathrm{BHT}$ and quercetin.

\section{Statistical analysis}

The data were expressed as the mean \pm standard deviation (SD) of three independent experiments and analyzed using one-way analysis of variance, Student's t-test and XLSTAT 2015.4.01 software. $P$-values of $<0.05$ were considered to be statistically significant.

\section{Results}

\section{Phytochemical screening}

The results of the phytochemical screening are shown in Table 1 and show that the extracts of Scyphocephalium ochocoa bark are rich in bioactive compounds. All extracts are rich in phenolic compounds (total polyphenols, tannins, total flavonoids and proantocyanidins). The water extract has an abundance of saponosides, 
Table 1 Results of the preliminary phytochemical screening

\begin{tabular}{|c|c|c|c|c|}
\hline \multicolumn{2}{|l|}{ Chemical groups } & Wat & Wat-eth & Eth \\
\hline \multicolumn{2}{|l|}{ Saponosids } & +++ & ++ & - \\
\hline \multicolumn{2}{|l|}{ polyphenols } & +++ & +++ & +++ \\
\hline \multicolumn{2}{|c|}{ Sterols and triterpenes } & ++ & ++ & +++ \\
\hline \multicolumn{2}{|l|}{ Oses and holosides } & + & ++ & +++ \\
\hline \multirow[t]{2}{*}{ Tannins } & Gallics & +++ & +++ & +++ \\
\hline & Catechics & +++ & +++ & +++ \\
\hline \multicolumn{2}{|l|}{ Alkaloids } & +++ & + & + \\
\hline \multirow[t]{4}{*}{ Cyanidins } & Flavons & +++ & - & + \\
\hline & Flavanons & - & - & - \\
\hline & Flavonols & - & +++ & - \\
\hline & Flavanonols & - & +++ & +++ \\
\hline \multicolumn{2}{|l|}{ Total flavonoids } & +++ & +++ & +++ \\
\hline \multicolumn{2}{|l|}{ Anthocyans } & - & - & - \\
\hline \multicolumn{2}{|l|}{ Proanthocyanidins } & +++ & +++ & +++ \\
\hline \multicolumn{2}{|l|}{ Anthracenics } & +++ & +++ & - \\
\hline \multicolumn{2}{|l|}{ Coumarins } & - & - & - \\
\hline \multirow[t]{4}{*}{ Cardiac glycosides } & Digitoxins & - & +++ & - \\
\hline & Digitoxigenins & - & - & - \\
\hline & Gitoxins & - & - & ++ \\
\hline & Gitoxigenins & +++ & - & - \\
\hline \multicolumn{2}{|l|}{ Reducing sugar } & - & - & - \\
\hline
\end{tabular}

$+++=$ Very abundant; $++=$ Abundant $;+=$ Not abundant; $-=$ Not detected; Wat $=$ Water; Eth $=$ Ethanol; Wat-Eth $=$ Water-ethanol

alkaloids, anthracenics and digitoxigenins while the water-ethanol extract has a strong presence of flavonols, flavanonols and digitoxins. In particular, the ethanol extract has an abundance of sterol, triterpenes, oses and holosides.

\section{Phenolic compound content}

The Table 2 presents the contents of total phenolic, total flavonoids, total tannins and total proanthocyanidins of extracts from Scyphocephalium ochocoa.

\section{Total phenolic}

The contents of total phenolic in terms of gallic acid equivalent (standard curve equation: $\mathrm{Y}=0.0012 \mathrm{X}$ $0.0004, R^{2}=0.990$ ) ranged from $1885.611 \pm 31.356$ to
$6284.667 \pm 3.333 \mathrm{mgGAE} / 100 \mathrm{~g}$ of drug and were abundants in water extracts.

\section{Total flavonoid}

Total flavonoids (standard curve equation: $\mathrm{Y}=0.0032 \mathrm{X}$ $+0.0077, \quad R^{2}=1$ ) ranged from $159.365 \pm 2.228$ to $480.406 \pm 51.498 \mathrm{mgEQ} / 100 \mathrm{~g}$ and were abundants in water extracts.

\section{Total tannins}

Levels of tannins were expressed in terms of tannic acid equivalent (TAE). The equation of the right-hand side of the proportioning of the total tannins by the reference method of European Community gave $\mathrm{Y}=0.0009 \mathrm{X}+$ 0.2088 with $R^{2}=1$. Total tannins are ranged from 194.667 \pm 7.286 to $1898.000 \pm 62.568 \mathrm{mg}$ EQ/ $100 \mathrm{~g}$ and were abundant in water extracts. There were abundant in water extracts than water-ethanol and ethanol extracts.

\section{Total proanthocyanidins contents}

Levels of proanthocyanidins were expressed in terms of apple proanthocyanidins equivalent (APE). The equation of the right-hand side of the proportioning of the proanthocyanidins by the $\mathrm{HCl}$-Butanol method gave $\mathrm{Y}=$ $0.0006 \mathrm{X}+0.0024$ with $\mathrm{R}^{2}=0.986$. Proanthocyanidin contents had ranged between $94.944 \pm 2.158$ to $1234.111 \pm$ $39.457 \mathrm{mg}$ APE/ $100 \mathrm{~g}$ of drug and are very abundant in all extracts of $S$. ochocoa.

\section{Antiangiogenic activity}

The antiangiogenic potential of the extracts was evaluated in vivo with the chicken chorioallantoic membrane (CAM) the eighth embryonic day. The fertilized eggs were treated with aqueous extracts $(60,125,250$ and $500 \mu \mathrm{g} / \mathrm{mL}$ ). The degree of vessel branches formation on CAM was scored $48 \mathrm{~h}$ later. The vessel density is the percentage of blood supply to the analysis area. It is inversely proportional to the degree of inhibition. In the presence of phosphate buffered saline (PBS) used as a negative control, the target area has a vascularization percentage of $100 \%$, corresponding to a normal vasculature with a number of vessels branches equal to 15 . The inhibitory potential of extracts was expressed through their inhibitory concentration fifty $\left(\mathrm{IC}_{50}\right)$. In the

Table 2 Results of phenolic compounds dosage

\begin{tabular}{lll}
\hline Phenolic compounds & Water & Water-ethanol \\
\hline TPC $^{a}$ (mgGAE/ $100 \mathrm{~g}$ of extract) & $6284.667 \pm 3.333$ & $1885.611 \pm 31.356$ \\
TFC (mgEQ/ $100 \mathrm{~g}$ of extract) & $480.406 \pm 51.498$ & $159.365 \pm 2.228$ \\
TTC (mgTAE/ $100 \mathrm{~g}$ of extract) & $1898.000 \pm 62.568$ & $194.667 \pm 7.286$ \\
TPC (mgAPE/ $100 \mathrm{~g}$ of extract) & $1234.111 \pm 39.457$ & $94.944 \pm 2.158$ \\
\hline
\end{tabular}

$\mathrm{TPC}^{\mathrm{a}}=$ Total phenolic content; TFC $=$ Total flavonoid content; TC = Total tannins content; TPC = Total proanthocyanidins content 
presence of sorafenib (positive control), the number of blood vessels branches is reduced to $6,2,1$ and 0 , respectively to a concentration of $60,125,250$ and $500 \mu \mathrm{g} /$ $\mathrm{mL}$ and respectively an ability to inhibition angiogenesis to $60 \%, 86.667 \%, 93.333 \%$ and $100 \%$ with $\mathrm{IC}_{50}=$ $0.197 \mu \mathrm{g} / \mathrm{mL}$. In the presence of the water extract of $S$. ochocoa, the number of blood vessels branches is reduced to $8,6,4$ and 0 , respectively to a concentration of $60,125,250$ and $500 \mu \mathrm{g} / \mathrm{mL}$ and respectively an ability to inhibition angiogenesis to $60 \%, 86.667 \%, 93.333 \%$ and $100 \%$ with $\mathrm{IC}_{50}=1.153 \mu \mathrm{g} / \mathrm{mL}$. All results are reported in Table 3 and Fig. 2. Compared to the reference molecule, the water extract of S. ochocoa has good antiangiogenic activity although this activity is lower than that of the reference.

\section{Drabkin reagent test}

Drabkin's reagent test determined the hemoglobin content of the dissected CAM sections. The results are summarized in Fig. 3. Considering that the hemoglobin content is $100 \%$ for the sections of CAM treated with the PBS (negative control), it is shown that in the presence of the variable concentrations of the drug of 60 , 125,250 and $500 \mu \mathrm{g} / \mathrm{mL}$, the hemoglobin content is $55 \%, 35 \%, 20 \%$ and $2 \%$, respectively for water extract. This content is $40 \%, 14 \%, 8 \%$ and $0 \%$, respectively for sorafenib. These data indicate that the hemoglobin content decreases with the number of branches of the blood vessels and is dependent on the concentration of the drug. This test therefore confirms the antiangiogenic activity observed.

\section{Toxicity of extracts}

The status of embryos after extracts action on vascularization inform on toxicity (Table 3 ). No embryo death was recorded in the concentration range tested indicating that the observed antiangiogenic activity is not due to the toxicity of the extracts.

\section{Anti-inflammatory activity}

The anti-inflammatory activity was assessed on the one hand by protein denaturation method [26, 27] and on the other hand by membrane stabilization method [29].

\section{Protein anti-denaturation test}

The results of protein anti-denaturation test are shown in Table 4. These results indicate that $S$. ochocoa extracts have good anti-denaturation activities with $\mathrm{IC}_{50}$ proteins ranging from $34.775 \pm 2.543 \mu \mathrm{g} / \mathrm{mL}$ to $74.577 \pm 3.456 \mu \mathrm{g} /$ $\mathrm{mL}$. Inhibition of protein denaturation is stronger with water-ethanol extract $\left(\mathrm{IC}_{50}=34.775 \pm 2.543 \mu \mathrm{g} / \mathrm{mL}\right)$. This anti-denaturation activity is similar to that of the reference drug, sodium diclofenac $\left(\mathrm{IC}_{50}=35.746 \pm\right.$ $2.374 \mu \mathrm{g} / \mathrm{mL})(p$ value $=0.582)$. In addition this activity is dependent on the concentration. Thus for extract concentrations of $6.25,12.5,25,50$ and $100 \mu \mathrm{g} / \mathrm{mL}$, the percentages of inhibitions are $17.588 \pm 1.553 \%, 33.040 \pm$ $2.442 \%, 38.317 \pm 1.797 \%, 46.357 \pm 1.599 \%$ and $65.201 \pm$ $1.178 \%$, respectively for water-ethanol extract.

\section{Membrane stabilization test}

The anti-inflammatory activity of S. ochocoa extract observed by inhibition of albumin denaturation is confirmed by membrane stabilization test. The results are summarized in Table 5. The extracts showed good inhibition of hemolysis of red blood cells.

For heat-induced hemolysis, all the extracts showed a very strong anti-hemolytic activity ( $\mathrm{IC}_{50}$ ranging from $36.793 \pm 0.529 \mu \mathrm{g} / \mathrm{mL}$ to $48.912 \pm 0.9573 \mu \mathrm{g} / \mathrm{mL}$ ) compared to the reference drug, sodium diclofenac $\left(\mathrm{IC}_{50}=180.911 \pm 2.205 \mu \mathrm{g} / \mathrm{mL}\right) \quad(p$ value $=0.001)$. The inhibition percentages of water extract are $46.850 \pm$ $0.059 \%, \quad 57.261 \pm 0.102 \%, \quad 56.985 \pm 0.120 \%, \quad 33.639 \pm$ $0.137 \%$ and $7.710 \pm 0.120 \%$ at respective concentrations of $250,125,62.5,31.25$ and $15.625 \mu \mathrm{g} / \mathrm{mL}$.

For hemolysis induced by a hypotonic solution, only the water extract was more active $\left(\mathrm{IC}_{50}=56.713 \pm\right.$ $0.492 \mu \mathrm{g} / \mathrm{mL}$ ) than the other two extracts.

Table 3 Antiangiogenic effect of S. ochocao and Sorafenib

\begin{tabular}{|c|c|c|c|c|c|c|c|}
\hline Drugs & $\begin{array}{l}\text { Dose } \mu \mathrm{g} / \mathrm{mL} \\
\text { per œuf }\end{array}$ & Tested eggs (n) & $\begin{array}{l}\text { Embryos status } \\
\text { after } 48 \mathrm{~h}\end{array}$ & $\begin{array}{l}\text { Branches vessels } \\
\text { nombers }\end{array}$ & \%AIA & $\mathrm{IC}_{50}(\mu \mathrm{g} / \mathrm{mL})$ & P value \\
\hline PBS (negative control) & - & 5 & living & $15 \pm 0.954$ & - & - & 0.002 \\
\hline \multirow[t]{4}{*}{ Sorafenib (positive control) } & 62.5 & 5 & living & $6 \pm 0.753$ & $60 \pm 1.056$ & \multirow[t]{4}{*}{$0.197 \pm 0.062$} & \\
\hline & 125 & 5 & living & $2 \pm 0.954$ & $86.667 \pm 1.045$ & & \\
\hline & 250 & 5 & living & $1 \pm 0.976$ & $93.333 \pm 0.965$ & & \\
\hline & 500 & 5 & living & 0 & 100 & & \\
\hline \multirow[t]{4}{*}{ Water extract of S. ochocao } & 62.5 & 5 & living & $8 \pm 0.834$ & $26.667 \pm 1.634$ & \multirow[t]{4}{*}{$1.153 \pm 0.089$} & \\
\hline & 125 & 5 & living & $5 \pm 0.850$ & $60 \pm 0.507$ & & \\
\hline & 250 & 5 & living & $3 \pm 0.500$ & $73.333 \pm 0.910$ & & \\
\hline & 500 & 5 & living & 0 & 100 & & \\
\hline
\end{tabular}

A significant difference is observed between the antiangiogenic effect of sorafenib and that of water extract of $S$. ochocoa $(p$ value $=0.002)$ 


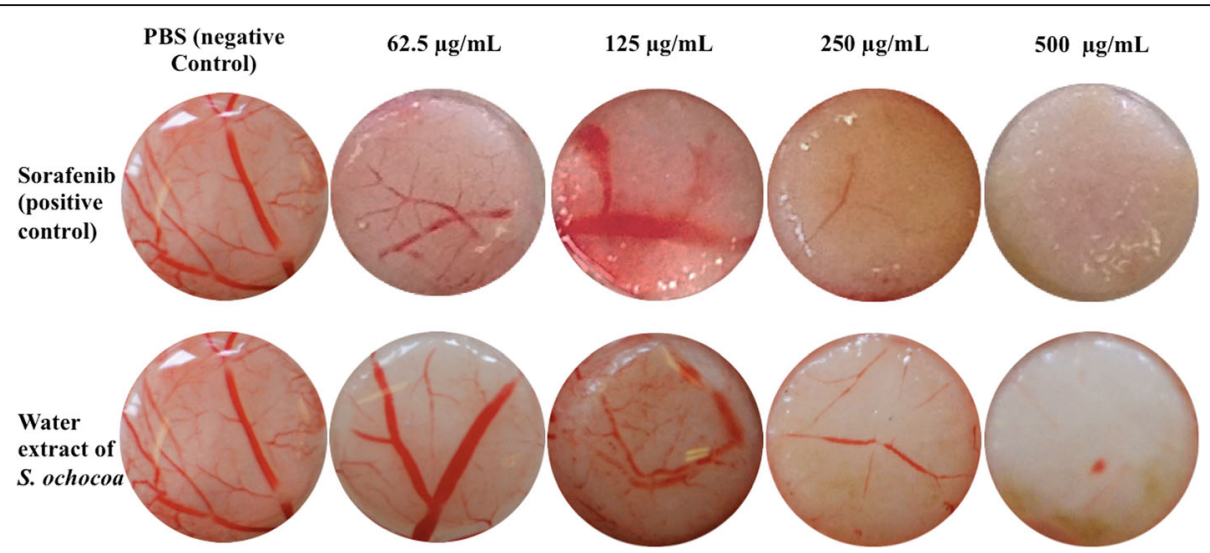

Fig. 2 Inhibitory effects of water extracts of plants on angiogenesis. The CAM of a 8 days old chick embryo was separately exposed to PBS (control). Extracts were introduced on top of the CAMs. After $48 \mathrm{~h}$ of incubation, the CAM tissue directly beneath each filter disk was resected, and digital images of the CAM sections were captured

Anti-hemolytic activity exhibited by the water extract is similar to that of sodium diclofenac $(58.590 \pm$ $1.021 \mu \mathrm{g} / \mathrm{mL})(\mathrm{p}$ value $=0.471)$.

The observation of the blood smears performed after the various treatments shows that red blood cells have a normal form in presence of an isotonic solution, in presence of water extract $(250 \mu \mathrm{g} / \mathrm{mL})$ and in presence of sodium diclofenac $(250 \mu \mathrm{g} / \mathrm{mL})$. In presence of a hypotonic solution, the haemolysis is complete and the limbs are disorganized in presence of low concentration of water extract $(15.625 \mu \mathrm{g} / \mathrm{mL})$ and sodium diclofenac (15.625 $\mu \mathrm{g} / \mathrm{mL}$ ) (Fig. 4).

\section{Antioxidant activity}

The antioxidant activity was evaluated by DPPH radical inhibition test and phosphomolybdenum method. The results are shown in Table 6. Compared with

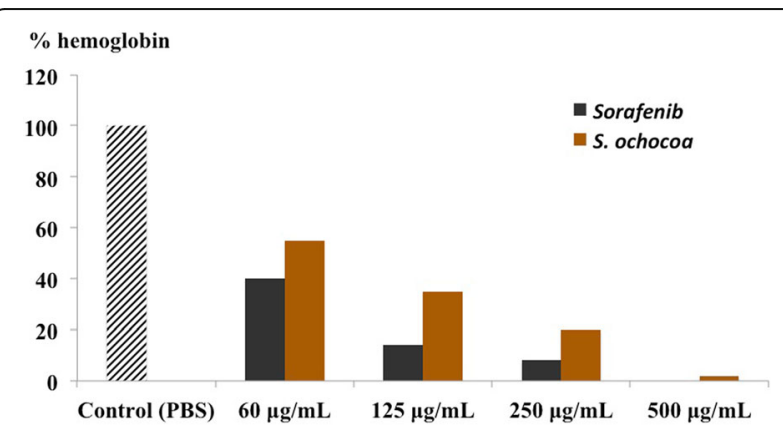

Fig. 3 Haemoglobin content of CAM sections detected by Drabkin's assay. The hemoglobin content in the CAM sections was determined by Drabkin method. As in the case of macroscopic observation of CAM that showed that the number of blood vessel branches was concentration dependent, so the present figure shows a hemoglobin content dependent on the concentration of $S$. Ochocoa water extract and sorafenib the other crude extracts, water-ethanol extract has a greater antioxidant activity marked by a stronger inhibition of DPPH radical $\left(\mathrm{IC}_{50}=4.969 \pm 0.263 \mu \mathrm{g} / \mathrm{mL}\right.$, $\mathrm{AAI}=10.080 \pm 0.517)$ and by a greater total antioxidant capacity $(87.766 \pm 0.852$ EQ $(\mathrm{mg}) / \mathrm{g}, 131.302 \pm$ $1.102 \mathrm{VtCE}(\mathrm{mg}) / \mathrm{g}$ and $570.364 \pm 5.307 \mathrm{BHTE}(\mathrm{mg}) / \mathrm{g}$ dry extract). Comparing this antioxidant activity with those of the reference molecules, it appears that water-ethanol extract has an antioxidant activity three times stronger than that of BHT $\left(\mathrm{IC}_{50}=13.759\right.$ $\pm 0.029 \mu \mathrm{g} / \mathrm{mL}$, AAI $=3.634 \pm 0.008)$, twice as strong as that of quercetin $\left(\mathrm{IC}_{50}=11.224 \pm 0.611 \mu \mathrm{g} / \mathrm{mL}\right.$, IAA $=4.463 \pm 0.245)$ and similar to that of vitamin $\mathrm{C}\left(\mathrm{IC}_{50}=\right.$ $4.597 \pm 0.095 \mu \mathrm{g} / \mathrm{mL}, \mathrm{AAI}=10.880 \pm 0.228)$. Other extracts also show good antioxidant activity with $\mathrm{IC}_{50}$ ranging from $8.373 \pm 0.242 \mu \mathrm{g} / \mathrm{mL}$ to $16.188 \pm 0.336 \mu \mathrm{g} / \mathrm{mL}$ and AAI ranging from $3.090 \pm 0.065$ to $5.975 \pm 0.172$.

\section{Discussion}

Cancer correspond to a rapid proliferation of abnormal cells that, beyond their usual boundaries, can invade adjacent parts of the body and then form metastases, which according to WHO are the leading cause of cancer deaths [4]. It is clearly established that reactive oxygen species (ROS), chronic inflammation and angiogenesis play an important role in initiation, tumor progression and metastasis formation [6, 7]. In order to contribute to the search for potential phyto-anticancer drugs, this preliminary study aimed to perform a phytochemical screening, to determine the content of phenolic compounds, to evaluate the antiangiogenic, anti-inflammatory and antioxidant activities of ethanol, water-ethanol and water extracts of $S$. ochocoa barks. This African medicinal plant is used in the treatment of several diseases such as female infertility, febrile body aches, gonorrhea, anemia, rheumatism, joint pain, 
Table 4 Effect of S. ochocoa extracts and diclofenac sodium against protein denaturation

\begin{tabular}{|c|c|c|c|c|c|}
\hline \multicolumn{4}{|c|}{$\%$ Inhibition of S. ochocoa extracts } & \multicolumn{2}{|c|}{ Sodium diclofenac } \\
\hline Conc. $(\mu \mathrm{g} / \mathrm{mL})$ & Water & Water-Ethanol & Ethanol & Conc. $(\mu \mathrm{g} / \mathrm{mL})$ & $\%$ Inhibition \\
\hline 100 & $66.332 \pm 1.777$ & $65.201 \pm 1.178$ & $56.281 \pm 1.264$ & 500 & $129.481 \pm 1.508$ \\
\hline 50 & $31.281 \pm 1.244$ & $46.357 \pm 1.599$ & $39.573 \pm 1.954$ & 250 & $103.015 \pm 2.970$ \\
\hline 25 & $17.714 \pm 1.178$ & $38.317 \pm 1.797$ & $32.161 \pm 2.132$ & 125 & $96.566 \pm 2.609$ \\
\hline 12.5 & $13.693 \pm 1.178$ & $33.040 \pm 2.442$ & $24.497 \pm 2.152$ & 62.5 & $71.106 \pm 3.048$ \\
\hline 6.25 & $4.899 \pm 1.533$ & $17.588 \pm 1.553$ & $10.678 \pm 1.244$ & 31.25 & $43.300 \pm 1.002$ \\
\hline $\mathrm{IC}_{50}(\mu \mathrm{g} / \mathrm{mL})$ & $74.577 \pm 3.456$ & $34.775 \pm 2.543$ & $40.345 \pm 3.567$ & & $35.746 \pm 2.374$ \\
\hline$P$ value & 0.014 & 0.582 & & & \\
\hline
\end{tabular}

There is no significant difference between the $\mathrm{IC}_{50}$ of the water-ethanol, ethanol extract and diclofenac $(p$ value $=0.582)$. On the other hand the difference is made with the water extract $(p$ value $=0.014)$

ovulation disorders, breast cancer, stomach cancer, skin cancer and liver cancer.

The results of the phytochemical screening revealed that the extracts of $S$. ochocoa are rich in total polyphenols, tannins, total flavonoids and proantocyanidins, saponosides, alkaloids, anthracenics and digitoxigenins, flavonols, flavanonols, digitoxins, sterol, triterpenes, oses and holosides. High levels of phenolic compounds (total polyphenol) were recorded. The polyphenol content of S. ochocoa is higher than that recorded in Oncoba welwitschii plants (with contents ranging from $232.050 \pm 2.200$ to $735.150 \pm$ $23.650 \mathrm{mgGAE} / \mathrm{g}$ ) and Tetrorchidium oppositifolium (with quantities ranging from $126.400 \pm 0.750$ to 718.100$)$. \pm 0.100 ) [32]. Several researchers have shown that polyphenols are highly active compounds against cancer, inflammatory diseases, cardiovascular, neuro-degenerative
(Parkinson's and Alzheimer's disease), are powerful antioxidants and antivirals agents [33].

The results also indicate that water extract has a strong anti-angiogenic activity marked by the inhibition of the formation of new blood vessels in the CAM. This activity is confirmed by Drabkin test which makes it possible to determine the hemoglobin level in the sections of CAM after treatment with the extracts. The hemoglobin level is proportional to the number of blood vessels. By comparison of $\mathrm{IC}_{50}$, the antiangiogenic activity of $S$ ochocoa $\left(\mathrm{IC}_{50}=1.153 \pm 0.089 \mu \mathrm{g} / \mathrm{mL}\right)$ is lower than that of the reference drug, sorafenib $\left(\mathrm{IC}_{50}=0.197 \pm\right.$ $0.062 \mu \mathrm{g} / \mathrm{mL})$. However, this activity is greater than that of Oncoba welwitschii and Tetrorchidium oppositifolium which at $500 \mu \mathrm{g} / \mathrm{mL}$ exhibit an antiangiogenic activity of 83.334\% [32] while at this same concentration, $S$.

Table 5 Effect of S. ochocoa extracts and diclofenac sodium against membrane stabilization

\begin{tabular}{|c|c|c|c|c|c|}
\hline & \multirow{2}{*}{$\begin{array}{l}\text { Conc. }(\mu \mathrm{g} / \\
\mathrm{mL})\end{array}$} & \multicolumn{3}{|c|}{$\%$ Inhibition of extracts from S. ochocoa } & \multirow{2}{*}{$\begin{array}{l}\text { Sodium diclofenac } \\
\% \text { Inhibition }\end{array}$} \\
\hline & & Water & Water-ethanol & Ethanol & \\
\hline \multirow[t]{7}{*}{ Hemolysis induced by hypotonicity } & 250 & $66.144 \pm 1.663$ & $56.867 \pm 1.948$ & $76.348 \pm 0.017$ & $100.000 \pm 0.000$ \\
\hline & 125 & $56.532 \pm 0.744$ & $50.626 \pm 0.452$ & $51.937 \pm 0.296$ & $100.000 \pm 0.000$ \\
\hline & 62.5 & $53.436 \pm 0.603$ & $43.873 \pm 0.152$ & $30.573 \pm 0.163$ & $99.583 \pm 1.078$ \\
\hline & 31.25 & $32.633 \pm 0.452$ & $21.256 \pm 1.285$ & $14.720 \pm 0.311$ & $99.132 \pm 1.068$ \\
\hline & 15.625 & $10.874 \pm 0.149$ & $10.539 \pm 1.095$ & $7.672 \pm 1.976$ & $0.885 \pm 0.121$ \\
\hline & $\mathrm{IC}_{50}(\mu \mathrm{g} / \mathrm{mL})$ & $56.713 \pm 0.492$ & $71.200 \pm 1.833$ & $133.375 \pm 0.661$ & $58.590 \pm 1.021$ \\
\hline & $P$ value & 0.471 & & 0.016 & 0.471 \\
\hline \multirow[t]{7}{*}{ Hemolysis induced by heat } & 250 & $46.850 \pm 0.059$ & $56.867 \pm 2.948$ & $69.822 \pm 2.791$ & $71.039 \pm 0.112$ \\
\hline & 125 & $57.261 \pm 0.102$ & $41.033 \pm 1.826$ & $56.118 \pm 3.369$ & $32.971 \pm 0.640$ \\
\hline & 62.5 & $56.985 \pm 0.120$ & $33.077 \pm 1.442$ & $35.542 \pm 2.841$ & $13.788 \pm 3.527$ \\
\hline & 31.25 & $33,639 \pm 0.137$ & $20.704 \pm 2.170$ & $12.777 \pm 1.437$ & $6.430 \pm 1.453$ \\
\hline & 15.625 & $7.710 \pm 0.120$ & $1.667 \pm 0.995$ & $7.553 \pm 1.878$ & $2.911 \pm 0.147$ \\
\hline & $\mathrm{IC}_{50}(\mu \mathrm{g} / \mathrm{mL})$ & $36.793 \pm 0.529$ & $39.526 \pm 0.710$ & $48.912 \pm 0.9573$ & $180.911 \pm 2.205$ \\
\hline & $P$ value & 0.273 & & & 0.001 \\
\hline
\end{tabular}

For hypotonicity-induced hemolysis, the ability to stabilize the membrane is similar for water extract, ethanol and diclofenac $(p$ value $=0.471)$. A significant difference is observed with ethanol extract ( $p$ value $=0.016$ )

For heat-induced hemolysis, all extracts have the same effect on membrane stabilization ( $p$ value $=0.273$ ). However, their effect is significantly different from that of diclofenac $(p$ value $=0.001)$ 


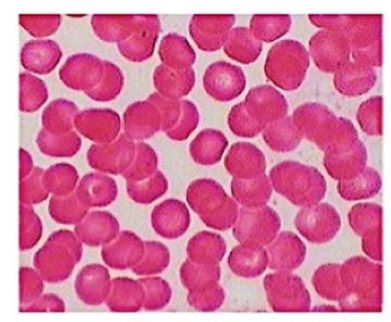

Normal cells (isotonic solution)

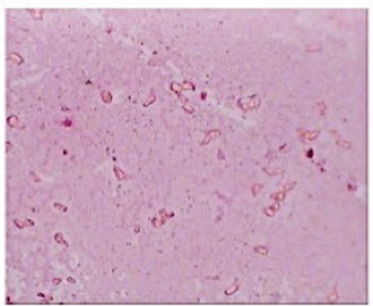

Total hemolysis with hypotonic solution

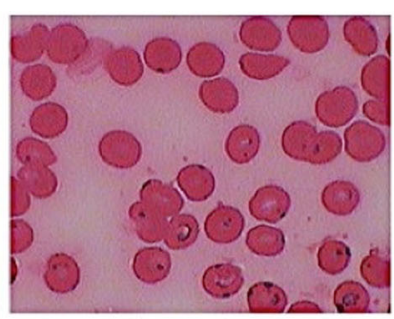

Water extracts $(250 \mu \mathrm{g} / \mathrm{mL})$

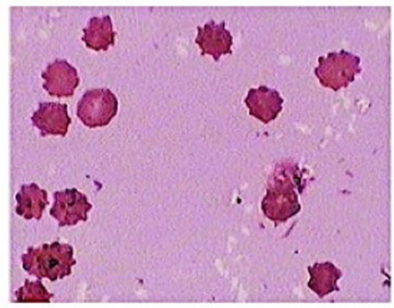

Water extracts (15.625 $\mu \mathrm{g} / \mathrm{mL}$ )

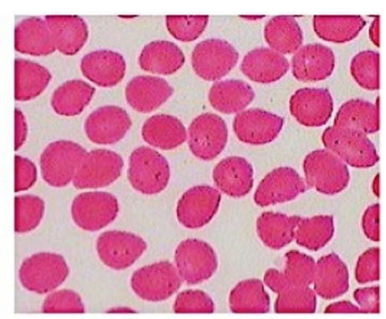

Diclofenac sodium $(250 \mu \mathrm{g} / \mathrm{mL})$

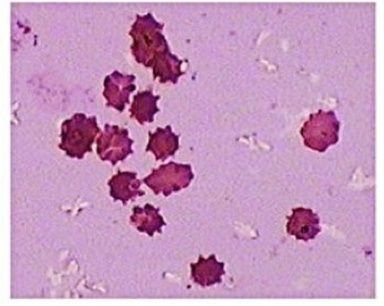

Diclofenac sodium $(15.625 \mu \mathrm{g} / \mathrm{mL})$

Fig. 4 Appearance of erythrocytes before and after the treatment with the extract and sodium diclofenac. The smear was performed before and after treatment with extracts and sodium diclofenac to observe the appearance of erythrocytes. Here it is the case of hemolysis induced by a hypotonic solution. It is well shown that at $250 \mu \mathrm{g} / \mathrm{mL}$ of drugs, erythrocytes have a normal form. However at low concentration $(15.625 \mu \mathrm{g} / \mathrm{mL})$, these cells have an irregular contour testifying to disorganization of the membrane but the cells are not lysed

ochocoa has a $100 \%$ activity. It is similar to the activity of Lophira procera, which has an inhibition of angiogenesis of $100 \%$ at $500 \mu \mathrm{g} / \mathrm{mL}$ [28]. From these results, it appears that water extract of $S$. ochocoa could be used in the treatment of angiogenesis-related diseases such as diabetic proliferative retinopathy, psoriasis, rheumatoid arthritis, atherosclerosis and cancers. The use of $S$. ochocoa as anticancer in traditional medicine could therefore be justified.

In addition to having antiangiogenic activity, S. ochocoa exhibited strong anti-inflammatory activities marked by inhibition of protein denaturation. Water-ethanol extract was more active than the other extracts and activity was similar to that of sodium diclofenac. It is well established that denaturation of tissue proteins leads to inflammatory and arthritic diseases [34]. As a result, phyto-substances that can inhibit protein denaturation may be useful for the research and development of anti-inflammatory drugs. The anti-inflammatory activity of $S$. ochocoa extracts was confirmed by erythrocyte membrane stabilization test. The results showed that at different concentrations of extracts, human erythrocyte membranes were protected against hypotonic solution-induced lysis and heat. Indeed, during the inflammatory reaction, lysosomes release their acidic lytic enzymes and pro-inflammatory mediators that will degrade most of the proteins [35]. The beneficial effect of nonsteroidal anti-inflammatory drugs (NSAIDs) is their ability to inhibit the release of lysosomal enzymes or their ability to stabilize lysosomal membranes [36]. Exposure of red blood cells to harmful substances such as hypotonic media and heat leads to membrane lysis,

Table 6 Results of antioxidant activity of S. ochocoa extracts

\begin{tabular}{|c|c|c|c|c|c|}
\hline \multirow[t]{2}{*}{ Samples } & \multicolumn{2}{|c|}{ Antioxidant activity DPPH assay } & \multicolumn{3}{|c|}{ Total antioxidant capacities } \\
\hline & $\mathrm{I}_{50}(\mu \mathrm{g} / \mathrm{mL})$ & AAl & $\mathrm{QE}(\mathrm{mg}) / \mathrm{g}$ dry extract & VtCE (mg)/g dry extract & BHTE $(\mathrm{mg}) / \mathrm{g}$ dry extract \\
\hline Eth ext & $8.373 \pm 0.242$ & $5.975 \pm 0.172$ & $77.207 \pm 0.704$ & $117.654 \pm 0.909$ & $504.606 \pm 4.382$ \\
\hline Wat-Eth ext & $4.969 \pm 0.263$ & $10.080 \pm 0.517$ & $87.766 \pm 0.852$ & $131.302 \pm 1.102$ & $570.364 \pm 5.307$ \\
\hline Wat ext & $16.188 \pm 0.336$ & $3.090 \pm 0.065$ & $15.309 \pm 0.770$ & $37.654 \pm 0.995$ & $119.152 \pm 4.792$ \\
\hline $\mathrm{BHT}$ & $13.759 \pm 0.029$ & $3.634 \pm 0.008$ & & & \\
\hline Quercetin & $11.224 \pm 0.611$ & $4.463 \pm 0.245$ & & & \\
\hline Vitamin C & $4.597 \pm 0.095$ & $10.880 \pm 0.228$ & & & \\
\hline
\end{tabular}

Wat ext. = Water extract; Eth ext. = Ethanol extract; Wat-Eth extract $=$ Water-ethanol extract; $\mathrm{QE}=$ Quercetin equivalent; VtCE $=$ Vitamin $\mathrm{C}$ equivalent; $\mathrm{BHTE}=\mathrm{BHT}$ equivalent 
followed by hemolysis and oxidation of hemoglobin [37]. Human erythrocyte membranes have been shown to be identical to lysosome membranes [36], so the antihemolytic effect of $S$. ochocoa extracts observed on erythrocytes can be transposed to lysosomes. The observation of blood smears shows that erythrocyte membranes are more stable in the presence of a concentration of $250 \mu \mathrm{g} / \mathrm{mL}$ of water extract and sodium diclofenac. Thus, S. ochocoa extracts can exert anti-inflammatory effect by membranes stabilization and prevent lytic enzymes release and pro-inflammatory active mediators.

Finally, all extracts of S. ochocoa showed strong antioxidant activities manifested by the inhibition of DPPH radical and by the reduction of Mo (VI) in Mo (V) leading to the formation of a complex Mo (V) of green phosphate. Water-ethanol extract showed greater antioxidant activity compared to the other extracts. It was shown that water-ethanol extract of $S$. ochocoa had an antioxidant activity half as much as that of vitamin $C$ with the respective $\mathrm{IC}_{50}$ values of $\mathrm{IC}_{50}=0.169 \pm 0.019 \mu \mathrm{g} / \mathrm{ml}$ and $\mathrm{IC}_{50}=0.267$ $\pm 0.009 \mu \mathrm{g} / \mathrm{mL}$ [38]. However, the results of this study show that water-ethanol extract of S. ochocoa has antioxidant activity similar to that of vitamin $C$. This extract has an antioxidant activity slightly above that of water-acetone extract of Englerina gabonensis $\left(\mathrm{IC}_{50}=5.67 \pm 0.32 \mu \mathrm{g} / \mathrm{mL}\right.$ ) [39]. $S$. ochocoa has a strong activity as the methanol extract of Syzygium rowlandii $\left(\mathrm{IC}_{50}=9.22 \pm 0.02 \mu \mathrm{g} / \mathrm{mL}\right)$ [40] and $\mathrm{Eu}$ calyptus citriodora $\left(\mathrm{IC}_{50}=34.2 \pm 2.3 \mu \mathrm{g} / \mathrm{mL}\right)$ [41].

It is well known that reactive oxygen species play an important role in angiogenesis, tumor progression and metastasis formation $[6,7]$. Once formed, the cancer cell secretes reactive oxygen species (ROS). These ROS will activate the hypoxia-inducing factor (HIF-1 $\alpha$ ) which will lead, on the one hand, to the secretion of vascular endothelial growth factors (VEGFs) whose role is to stimulate the proliferation and migration of endothelial cells to increase the microvascular permeability. These VEGFs will interact with their receptors (VEGFR2) and induce neovascularization [8]. On the other hand, HIF-1 $\alpha$ will induce the production of matrix metalloproteinases 2 and 9 (MMP 2 and 9), which will degrade membranes and cause tumor expansion. ROS can also interact directly with VEGF receptors and induce angiogenesis or oxidize lipids that will interact with Toll receptors and activate nuclear kappa B (NF-kB) factors that are a transcription factor involved in immune response and response in cell stress, its activation triggers the transcription of anti-apoptotic genes in the nucleus [42]. ROS can also induce the production of thioredoxin which leads to the synthesis of matrix metalloproteinases 9 [8]. As a result, a phyto-product with a high content of polyphenols and flavonoids, with good anti-angiogenic, anti-inflammatory and antioxidant activities such as extracts of $S$. ochocoa could be an ideal candidate for the development of anticancer drugs.

\section{Conclusion}

In conclusion, this study provides convincing evidence that bark extracts of Scyphocephalium ochocoa have beneficial health effects. Water, water-ethanol and ethanol extracts of barks showed high levels of polyphenols, flavonoids, tannins and proanthocyanidins. The phyto-constituents identified in water, water-ethanol and ethanol extracts of S. ochocoa were found to be biologically active by their antiangiogenic ability manifested by the inhibition of the news branches vessels formation on CAM model. Then by their powerful anti-inflammatory effects marked by the inhibition of the denaturation of the proteins and by the stabilization of the erythrocyte membranes. Finally by their strong antioxidant activities in terms of reducing power and a significant ability to trap the DPPH radicals. The water extract is richer in phenolic compounds, has a stronger anti-inflammatory activity than the other extracts and very active on angiogenesis. These results could justify the use of S. ochocoa extracts in traditional medicine in the treatment of cancers, other diseases related to angiogenesis (diabetic retinopathy, rheumatoid arthritis, plaque of atherosclerosis), inflammatory diseases due to pathogenicity microbial and oxidative stress caused by the overproduction of radicals.

\section{Abbreviations \\ AAl: Antioxidant activity index; AlA: Ability to inhibition angiogenesis; APE: Apple procyanidins equivalent; BHT: Butylated hydroxytoluene; BHTE: BHT equivalent; CAM: Chicken chorioallantoic membrane; DPPH: 2,2- diphenyl-1-picryl-hydrazyl; EDTA: Ethylene diamine tetraacetic acid; GAE: Gallic acid equivalent; HIF-1a: Inducing factor of hypoxia; MMP: Matrix metalloproteinases; NF-kB: Kappa B nuclear factors; NSAIDs: Non-steroidal anti-inflammatory drugs; PBS: Phosphate-buffered saline; QE: Quercetin equivalent; TAE: Tannic acid equivalent; TFC: Total flavonoid content; TNFa: Tumor necrosis factor-a; TPC *: Total phenolic content; TPC: Total proanthocyanidins content; TTC: Total tannins content; VEGF: Vascular endothelial growth factor; VtCE: Vitamin C equivalent}

\begin{abstract}
Acknowledgements
The authors are very much thankful to Shell Gabon for the financial support of materials in Laboratory of Research in Biochemistry (LAREBIO) USTM, Franceville-Gabon. We are very much grateful to local informants and Mr. Meye Misso Paul-Edouard who shared their knowledge on the use of medicinal plants with us. We also thank Mr. Meye M'Ella Antoine, Mr. Allogho Essono Judicaël and Ms. Ada Mengome Meredith for their participation.
\end{abstract}

\section{Funding}

Laboratory of Research in Biochemistry (LAREBIO), Department of ChemistryBiochemistry, Faculty of Sciences of USTM in Franceville has partially supported this research work. The authors have no other affiliation or financial involvement with any organization.

\section{Availability of data and materials}

All data and materials are contained and described in the manuscript. The dataset has been deposited in publicly available repositories. The barks of $S$. ochocoa were collected August 2015 in Mitzic, Woleu-Ntem (Northern of Gabon). They have been identified at the National Herbarium of IPHAMETRA, Libreville (Gabon). Voucher specimen has been deposited in the Herbarium of IPHAMETRA and Laboratory of Biochemistry Research (LAREBIO), Department of Chemistry-Biochemistry, Faculty of Sciences of USTM, Franceville. 


\section{Authors' contributions}

RLNMM is the lead author, designed the study, developed the protocols, analyzed the data and drafted the manuscript. JDLCN reviewed the protocols, provided material support, and made corrections to the manuscript. CSO participated in all the experiments and the manuscript. JPO and GRNA participated in the interpretation and analysis of the data. FOA is Head of Laboratory of Biochemistry and the Mixed Unit for Biomedical Research, University of Health Sciences, Libreville, Gabon. LCOE, Head Laboratory of Research in Biochemistry, oversaw this work and made the necessary editorial corrections and gave final approval for the submission of the revised version. All authors have read and approved the final version.

\section{Authors' information}

Rick-Léonid Ngoua-Meye-Misso is a PhD student in BiochemistryPharmacology-Oncology at Doctoral School of Fundamental and Applied Sciences, University of Science and Technology of Masuku, Franceville, Gabon. Jean De La Croix NDONG as Research Professor at Ear, Nose and Throat Laboratory, Department of Otolaryngology-Head and Neck Surgery, Emory School of Medicine, Atlanta, USA. Sima-Obiang Cedric, Ondo Joseph-Privat and Ndong-Atome Guy-Roger work as a Research Professor in the Department of Chemistry-Biochemistry, University of Science and Technology Masuku, Franceville, Gabon. Ovono-Abessolo Felix is a Doctor, Associate Professor in Department of Chemistry-Biochemistry, University of Health Sciences, Libreville, Gabon. Finally, Obame-Engonga Louis-Clément is a Professor in Department of Chemistry-Biochemistry, University of Science and Technology Masuku, Franceville, Gabon.

\section{Ethics approval and consent to participate}

The study protocol was performed according to the Helsinki declaration and All volunteers have completed informed consent. The study protocol was approved by the Ethics Committee of Gabon ( $N^{\circ} 009$ March 2013).

\section{Competing interests}

The authors declare that there are no competing interests.

\section{Author details}

${ }^{1}$ Laboratory of Research in Biochemistry (LAREBIO), University of Sciences and Technology of Masuku, Franceville, Gabon. ${ }^{2}$ Laboratory of Natural Substances and Organometallic Synthesis, University of Sciences and Technology of Masuku, Franceville, Gabon. ${ }^{3}$ Department of Otolaryngology-Head and Neck Surgery, Ear, Nose and Throat Laboratory, Emory School of Medicine, Atlanta, USA. ${ }^{4}$ Laboratory of Biochemistry, Joint Unit of Biomedical Research, University of Health Sciences, Libreville, Gabon. ${ }^{5}$ Department of Chemistry and Biochemistry, Faculty of Science, University of Science and Technology of Masuku, Franceville, Gabon.

Received: 15 February 2018 Accepted: 21 May 2018

Published online: 08 June 2018

\section{References}

1. Letouzey R. Manuel de botanique forestière, Afrique Tropicale, Centre technique forestier d'Afrique tropicale Tome 2, Botanique Générale, 2 è éd. Paris; 1972, 423.

2. Walker R, Sillans S. Plantes utiles du Gabon. Ed Lechevalier. Sepia; 1961.

3. Bouquet A. Féticheurs et médecines traditionnelles du congo (Brazzaville). Paris: Mémoires O.R.S.T.O.M. №36; 1969.

4. OMS. Cancer Aide-mémoire N²97. In: OMS-Centre des médias. 2018. http:// www.who.int/fr/news-room/fact-sheets/detail/cancer. Accessed 29 Apr 2018

5. Ferlay J, Shin HR, Bray F, Forman D, Mathers C, Parkin DM. Les estimations de la charge mondiale du cancer en 2008: Globocan 2008. Int J Cancer. 2010;127:2893-917.

6. Coussens LM, Werb Z. Inflammation and cancer. Nature. 2002;420:860-7.

7. Liou GY, Storz P. Reactive oxygen species in cancer. Free Radic Res. 2010; 44(5):1-31.

8. Tonissen K, Bhatia M, Karlenius T, Trapani GD. The interaction between redox and hypoxic Signalling pathways in the dynamic oxygen environment of Cancer cells. In: Tonissen K, editor. Carcinogenesis. Rijeka: InTech; 2013. https://doi.org/10.5772/55185.

9. Balkwill F, Mantovani A. Inflammation and cancer: back to Virchow? Lancet. 2001;357:539-45.
10. Balkwill F. Tumor necrosis factor or tumor promoting factor? Cytokine Growth Factor Rev. 2002;13:135-41.

11. Baron JA, Sandler RS. Nonsteroidal anti-inflammatory drugs and cancer prevention. Annu Rev Med. 2000;51:511-23.

12. Garcia-Rodriguez LA, Huerta-Alvarez C. Reduced risk of colorectal cancer among long-term users of aspirin and nonaspirin nonsteroidal antiinflammatory drugs. Epidemiology. 2001;12:88-93.

13. Rossi D, Zlotnik A. The biology of chemokines and their receptors. Annu Rev Immunol. 2000;18:217-42.

14. Folkman J, Shing Y. Angiogenesis. J Biol Chem. 1992;267(16):10931-4.

15. Folkman J. Tumor angiogenesis: therapeutic implications. N Engl J Med. 1971;285:1182-6.

16. Ciulei, I. Methodology for Analysis of Vegetable Drugs. Practical Manual on the Industrial Utilisation of Medicinal and Aromatic Plants. Romania: Bucharest. 1982;1-62.

17. Sofowora A. Medicinal plants and traditional. Ibadan Nigeria: Medicine in Africa Spectrum books Ltd; 1993. p. 289.

18. Vernon LS, Orthofer R, Raventos LRM. Analysis of total phenols and other oxidation substrates and antioxidants by means of Folin-Ciocalteu reagent. Methods Enzymol. 1999;299:152-78.

19. Quettier-Deleu C, Gressier B, Vasseur J, Dine T, Brunet C. Phenolic compounds and antioxidant activities of buckwheat (Fagopyrum esculentum Moench) hulls and flour. J Ethnopharmacol. 2000;72:35-42.

20. Standard method for determining the tannins in sorghum. Official Journal of the European Communities No L 197/ 19; 1984. https://eur-lex.europa.eu/ legal-content/EN/TXT/PDF/?uri=CELEX:31984R2159\&from=FR.

21. Prigent $\mathrm{S}$. Interactions of phenolics compounds with globular proteins and their effects on food related functional properties. PhD Thesis, Wageningen University, Wageningen, The Netherlands. 2005; 131-133.

22. Ribatti D, Nico B, Vacca A, Presta M. The gelatin sponge-chorioallantoic membrane assay. Nat Protoc. 2006;1(1):85-91.

23. Ribatti D. Chick embryo chorioallantoic membrane as a useful tool to study angiogenesis. Int Rev Cell Mol Biol. 2008;270:181-224.

24. Drabkin DL, Austin JH. Spectrophotometric studies II. Preparations from washed blood cells; nitric oxide hemoglobin and sulfhemoglobin. J Biol Chem. 1935:112:51-65.

25. Yi J-M, Bang OS, Kim NS. An evaluation of the anti-angiogenic effect of the Korean medicinal formula Sa-mi-yeon-geon-tang in vitro and in ovo. BMC Complement Altern Med. 2015;15:42.

26. Williams LAD, O'Connar A, Latore L, Dennis O, Ringer $S$, Whittaker JA, et al. The in vitro Anti-denaturation effects induced by natural products and nonsteroidal compounds in heat treated (Immunogenic) Bovine Serum Albumin is proposed as a screening assay for the detection of antiinflammatory compounds, without the use of animals, in the early stages of the drug discovery process. West Indian Med J. 2008;57(4):327-31.

27. Chatterjee P, Chandra S, Dey P, Bhattacharya S. Evaluation of antiinflammatory effects of green tea and black tea: a comparative in vitro study. J Adv Pharm Technol Res. 2012;3(2):136-8.

28. Ngoua-Meye-Misso RL, Sima-Obiang C, Ndong JDLC, Ondo JP, Abessolo FO, Obame-Engonga LC. Phytochemical screening, antioxidant, anti-inflammatory and antiangiogenic activities of Lophira procera a. Chev. (Ochnaceae) medicina plant from Gabon. Egyp Jour Bas App Sci. 2018;5(1):80-6.

29. Shinde UA, Phadke AS, Nair AM, Mungantiwar AA, Dikshit VJ, Sarsf MN. Membrane stabilization activity a possible mechanism of action for the antiinflammatory activity of Cedrus deodara wood oil. Fitoterapia. 1989:70:251-7.

30. Scherer R, Godoy HT. Antioxidant activity index (AAl) by 2,2-diphenyl- 1picrylhydrazyl method. Food Chem. 2009;112:654-8.

31. Kubola J, Siriamornpun S. Phenolic content and antioxidant activities of bitter gourd (Momordica charantia L.) leaf stem and fruit fraction extracts in vitro. Food Chem. 2008;1 10:881-90.

32. Ngoua-Meye-Misso RL, Ondo JP, Assam EJN, Orango BJO, Sima-Obiang C, Ndong JDLC, et al. Phytochemical screening, antioxidant and antiangiogenic properties of Oncoba welwitschii (Oliv.) Gilgn. And Tetrorchidium oppositifolium (Pax. And Khoffm.), medicinal plants from Gabon. Int J Innov Res Sci Eng Technol. 2017:6:1-10.

33. Lacaille-Dubois MA, Wagner H. Importance pharmacologique des dérivés polyphénoliques. Acta Botanica Gallica. 1996;143(6):555-62.

34. Opie-EL. On the relation of necrosis and inflammation to denaturation of proteins. J Exp Med 1962; 115(3): 597-608.

35. Chayen J, Bitensky L. Lysosomal enzymes and inflammation with particular reference to rheumatoid diseases. Ann Rheum Dis. 1971;30:522-36. 
36. Mounnissamy VM, Kavimani S, Balu V, Quine SD. Evaluation of antiinflammatory and membrane stabilizing properties of ethanol extract of Cansjera reheedii J.Gmelin (Opiliaceae). Iranian J Pharmacol Therapeut. 2007; 6(2):235-0.

37. Feirrali M, Signormi C, Ciccolili L, Comporti M. Iron release and membrane damage in erythrocytes exposed to oxidizing agents, phenylhydrazine, devicene and iso-uranil. Biochem J. 1992;285:295-301.

38. Feuya TGR, Foundikou H, Lebibi J, Choudhary MI, Menkem EZ, Nantia EA, et al. Phytochemical analysis, antioxidant and antimicrobial properties of the leaves and stem bark of Scyphocephalium ochocoa Warb (Myristicaceae). J Pharmacogn Nat Prod. 2015;1:111.

39. Sima-Obiang C, Ngoua- Meye-Misso RL, Ndong-Atome GR, Ondo JP, ObameEngonga LC, Nsi-Emvo E. Chemical composition, antioxidant and antimicrobial activities of stem barks of Englerina gabonensis Englerand Sterculia tragacantha Lindlfrom Gabon. Int J Phytomedicine. 2017:9(3):501-10.

40. Obame-Engonga LC, Abdoul-Latif-Fatouma M, Ondo JP, Sima-Obiang C, Ngoua-Meye-Misso RL, Traoré A, et al. phytochemical screening, antioxidant and antibacterial activities of Guibourtia ehie and Syzygium rowlandii medicinal plants from Gabon. Int J Curr Res. 2017;9(8):56354-60.

41. Obame-Engonga LC, Sima-Obiang C, Ngoua-Meye-Misso RL, Orango BJO, Ondo JP, Ndong-Atome GR et al. Larvicidal and ovicidal properties against Anopheles gambiae, antioxidant and antibacterial activities of the combination of essential oils Eucalyptus citriodora, Cymbopogon giganteus and Cymbopogon nardus from Gabon. J Multidiscip Eng Sci Technol 2017; 4(8): 7887-7894.

42. Kim YW, Byzova TV. Oxidative stress in angiogenesis and vascular disease. Blood. 2014;123:625-31.

\section{Submit your manuscript to a SpringerOpen ${ }^{\circ}$ journal and benefit from:}

- Convenient online submission

Rigorous peer review

- Open access: articles freely available online

- High visibility within the field

- Retaining the copyright to your article

Submit your next manuscript at $\gg$ springeropen.com 